Irma W, Dyah N, Cherry T dan Usken F, Patogenisitas Bakteri, Jamur Dan Nematoda Entomopatogen Terhadap Hama Penggerek Buah Kapas (Gossypium hirsutum L.)

\title{
PATOGENISITAS BAKTERI, JAMUR DAN NEMATODA ENTOMOPATOGEN TERHADAP HAMA PENGGEREK BUAH KAPAS (Gossypium hirsutum L.)
}

\author{
Oleh: \\ IRMA WARDATI, DYAH NUNING ERAWATI, \\ CHERRY TRIWIDIARTO dan USKEN FESDIANA *)
}

\begin{abstract}
ABSTRAK
Salah satu alternatif pemecahan pengendalian hama utama tanaman kapas adalah dengan teknik pengendalian hama yang aman bagi lingkungan dan dapat menekan residu kimia pada produk pertanian (pengendalian hayati). Pengendali hayati (agens hayati) yang mempunyai potensi besar sebagai pengendali alami hama tanaman kapas antara lain adalah dari golongan bakteri, jamur dan nematoda entomopatogen. Pengembangan agens hayati yang efektif dan efisien sebagai pengendali hama sangat penting untuk dapat meningkatkan produktivitas tanaman kapas dengan tetap memperhatikan kualitas lingkungan hidup yang aman. Penelitian ini bertujuan untuk menganalisis dan menguji patogenisitas bakteri, jamur dan nematoda entomopatogen dalam mengendalikan hama penggerek buah kapas, serta untuk memperoleh isolat lokal bakteri, jamur dan nematoda entomopatogen yang paling efektif sebagai pengendali hama utama tanaman kapas. Penelitian ini menggunakan Rancangan Acak Lengkap (RAL), terdiri atas lima faktor perlakuan dengan lima ulangan, yaitu isolat lokal bakteri Bacillus thuringiensis, jamur Beauveria bassiana 1, jamur Beauveria bassiana 2, nematoda Steinernema sp. dan kontrol. Analisis data menggunakan uji F dan selanjutnya menggunakan Uji Jarak Ganda Duncan (UJGD). Parameter yang diamati terdiri atas: (1) Gejala kematian serangga uji; (2) persentase mortalitas serangga uji; (3) perilaku serangga uji terinfeksi; (4) laju kematian serangga uji; dan (5) bedah serangga uji terinfeksi. Hasil penelitian menunjukkan bahwa agens hayati bakteri Bacillus thuringiensis (Bt), jamur Beauveria bassiana (Bv) dan nematoda entomopatogen Steinernema sp. (NEP) berpotensi dalam menekan hama penggerek buah kapas Helicoverpa armigera, sedangkan agens hayati yang paling efektif dalam mengendalikan Helicoverpa armigera adalah isolat lokal jamur Beauveria bassiana 1, dengan waktu kematian tercepat yaitu 128 jam.
\end{abstract}

Kata Kunci: patogenisitas, bakteri, jamur, nematoda, hama penggerek buah kapas 
Irma W, Dyah N, Cherry T dan Usken F, Patogenistias Bakteri, Jamur Dan NematodaEntomopatogen Terhadap Hama Penggerek Buah Kapas (Gossypium hirsutum L.)

\section{PENDAHULUAN}

Kapas merupakan salah satu komoditas penting, karena menjadi bahan baku utama industri tekstil. Kebutuhan bahan baku serat terus meningkat mencapai sekitar 464.000 ton pertahun, sedangkan produksi nasional hanya mampu menyediakan sekitar 2600 ton $( \pm 0,6 \%)$, dari kebutuhan tersebut, sehingga setiap tahunnya diperlukan impor kapas sebesar 99,4\% dari kebutuhan. Rendahnya produksi kapas dalam negeri, selain karena menurunnya areal tanaman kapas sejak 1984/1985 seluas 46.380 ha, menjadi sekitar 16000 ha pada tahun terakhir, juga karena rendahnya produktivitas yang dicapai yaitu sekitar $500 \mathrm{~kg} / \mathrm{ha}$ kapas berbiji ((Disbun, 1998 dan Ditjenbun, 2001 dalam BPTP Sulsel, 2002).

Masalah utama perkapasan adalah tingginya intensitas serangan hama kapas terutama hama pengisap daun dan penggerek buah. Kehilangan hasil akibat hama pengisap daun dapat mencapai 53,9 \% (Isdiyoso dan Subandrio 1988 dalam BPTP Sulsel, 2002) dan penggerek buah sampai $90 \%$ (Karsyono, 1988 dalam BPTP Sulsel, 2002). Selama ini pengendalian yang dilakukan masih secara kimiawi dengan menggunakan pestisida kimia sintetik, yang menimbulkan banyak dampak negatif, antara lain resistensi hama, resurjensi hama, letusan hama ke dua dan residu senyawa kimia pada produk pertanian.

Dari 64 spesies serangga dan tungau hama kapas yang diinventarisasi sampai saat ini, hama yang utama di semua daerah pengembangan adalah wereng kapas (Sundapteryx biguttula Ishida), penggerek pucuk (Earias sp.) dan ulat penggerek buah kapas (Helicoverpa armigera Hubner). Pengendalian serangga hama yang diterapkan sampai saat ini adalah secara kimiawi, dengan sistem kalender, menggunakan sekitar 12 liter insektisida tiap hektar setiap musim. Ternyata sistem ini semakin tidak efektif dan menimbulkan dampak samping yang merugikan, seperti timbulnya reserjensi dan resistensi serangga terhadap insektisida, serta rusaknya populasi musuh alami. Dampak ini selanjutnya mengakibatkan biaya pengendalian makin tinggi dan produktivitas serta kualitas seratnya menurun. Untuk menghindari akibat buruk lebih lanjut, maka pemakaian insektisida perlu terus dikurangi. Hal ini dapat dilakukan dengan menerapkan teknik pengendalian hama secara terpadu (Subandrijo dkk., 2001).

Beberapa teknologi yang sudah siap diterapkan adalah pengendalian secara budidaya, yang meliputi sanitasi lahan, waktu tanam yang tepat dan serentak, penggunaan varietas resisten, penggunaan tanaman perangkap dan penerapan pola tanam yang tepat. Selanjutnya juga dilakukan pengendalian mekanis untuk serangga hama tertentu dan pengendalian hayati dengan konservasi dan pelepasan parasitoid maupun predator (Subandrijo dkk., 2001).

Penelitian-penelitian untuk memperoleh paket teknologi pengendalian hama terpadu (PHT) serangga hama kapas telah dimulai lebih dari 10 tahun yang lalu. Sekitar 15 komponen teknologi yang sebagaimana terdiri atas non kimiawi telah diperoleh dan dapat dirakit satu sama lain untuk memperoleh hasil yang efisien. Komponenkomponen tersebut termasuk dalam (1) pengendalian secara mekanik, (2) pengendalian secara budidaya, (3) pengendalian secara hayati, (4) pengendaliang secara kimiawi, (5) pengendalian menggunakan undang-undang, yang seluruhnya mengacu kepada prinsip dasar PHTPerkebunan. Prinsip dasar tersebut adalah: (1) budidaya tanaman sehat, (2) pelestarian musuh alami, (3) pengamatan berkala dan (4) petani menjadi ahli PHT. Setiap tahun dilakukan penyempurnaan penelitian sebelumnya, secara mencari terobosan baru untuk melengkapi pengendalian terpadu terhadap serangan hama kapas ini (Subandrijo, 2000).

Salah satu alternatif pengendalian hama yang aman bagi lingkungan dan dapat menekan residu kimia pada produk pertanian, tidak terkecuali bagi tanaman kapas adalah dengan pengendalian hayati. Pengendalian hayati merupakan suatu teknik pengendalian organisme pengganggu tanaman dengan memanfaatkan potensi keanekaragaman jenis agens pengendali alami untuk mengelola organisme pengganggu tanaman agar tidak mencapai batas populasi yang merugikan (Untung, 1996). Pengendali hayati (agens hayati) yang mempunyai potensi besar sebagai pengendali alami hama termasuk dalam golongan bakteri, jamur dan nematoda entomopatogen.

Baehaki (1993) mengungkapkan bahwa Bacillus thuringiensis yang merupakan bakteri entomopatogen dapat digunakan untuk mengendalikan Crocidolomia binotalis, Plutella xylostella, Thosea asigna, Setora nitens, Chillo sacchariphagus dan Scirpophaga nivela. Sedangkan jamur entomopatogen seperti Beauveria bassiana dengan konsentrasi 4 gram/10 liter mampu mengendalikan nimfa dan imago Helopelthis antonii sebesar 70-100\%. Konsentrasi

spora kering 2 gram/10 liter menurunkan serangan penggerek buah kakao hingga menjadi $29,92 \%$. Hypothenemus hampei pada buah kopi ditemukan 
Irma W, Dyah N, Cherry T dan Usken F, Patogenistias Bakteri, Jamur Dan NematodaEntomopatogen Terhadap Hama Penggerek Buah Kapas (Gossypium hirsutum L.)

terinfeksi oleh B. bassiana berkisar antara 38,\%$57,48 \%$ setelah dua minggu aplikasi (Sulistyowati dan Junianto, 2000). Selanjutnya, Erawati (2006) melaporkan bahwa hasil uji patogenisitas nematoda entomopatogen Steinernema carpocapsae terhadap larva hama $S$. litura mencapai $84 \%$ pada 72 jam setelah aplikasi. Hasil uji di lapang memperlihatkan bahwa kombinasi perlakuan $B$. bassiana dan $S$. carpocapsae memberikan tingkat penekanan intensitas kerusakan daun oleh larva S. litura yang tinggi. Hubungan kedua jenis agens hayati ini tidak bersifat antagonis (Erawati, 2007a).

Pengembangan pengendali hayati (agens hayati) yang efektif dan efisien sebagai pengendali hama sangat penting untuk dapat meningkatkan produktivitas tanaman kapas dengan tetap memperhatikan kualitas lingkungan hidup yang aman. Oleh karena itu, penelitian tentang patogenisitas bakteri, jamur dan nematoda entomopatogen terhadap hama utama tanaman kapas penting untuk dilaksanakan, guna mengembangkan penggunaan agens hayati untuk mengendalikan hama utama tanaman kapas yang belum banyak dilakukan oleh petani kapas.

Berdasarkan latar belakang yang telah dikemukakan, maka tujuan dalam penelitian ini adalah untuk menganalisis dan menguji patogenisitas bakteri, jamur dan nematoda entomopatogen dalam mengendalikan hama penggerek buah kapas, serta untuk memperoleh isolat lokal bakteri, jamur dan nematoda entomopatogen yang paling efektif sebagai pengendali hama penggerek buah kapas.

\section{METODOLOGI}

Penelitian ini termasuk dalam jenis penelitian eksperimen (experiment research). Penelitian eksperimen di dalam penelitian ini digunakan untuk maksud penjelasan (explanatory) atau konfirmatori (confirmatory), yakni untuk menjelaskan pengaruh antar variabel atau hubungan kausal antar variabel-variabel melalui pengujian hipotesis.

Penelitian dilaksanakan Laboratorium Perlindungan Tanaman Jurusan Produksi Tanaman Politeknik Negeri Jember. Penelitian dilakukan pada bulan Maret sampai dengan bulan Oktober 2011.

Bahan yang digunakan adalah larva uji $H$. armigera, PDA, alkohol, spirtus, aquades, kapas, alumuniun foil dan kertas label.
Alat yang digunakan, yaitu autoclave, laminar air flow, neraca analitis, erlenmeyer, cawan petri, jarum ose, tabung reaksi, oven, shaker, penangas air, mikropipet, klonning plate, hand counter, haemocytometer, gelas ukur, magnetic stirer, kompor, kuas, mikroskop, dan pinset.

Penelitian disusun berdasar Rancangan Acak Lengkap (RAL) faktor tunggal dengan 5 (lima) ulangan. Model linier untuk Rancangan Acak Lengkap adalah (Gomes dan Gomes, 1995):

$Y_{i j}=\mu+\tau_{i+} \varepsilon_{i j}$, yaitu:

$Y_{i j}$ : pengamatan pada perlakuan ke-i dan ulangan ke-j

$\mu \quad$ : nilai rata-rata populasi

$\tau_{i} \quad: \quad$ pengaruh perlakuan ke-i

$\varepsilon_{i j}:$ komponen random yang bekerja pada plot perlakuan ke-i dan ulangan ke-j

Faktor tunggal berupa strain agens hayati, yaitu:

1. Isolat lokal B. thuringiensis (A1)

2. Isolat lokal B. bassiana 1 (A2)

4. Isolat lokal B. bassiana 2 (A3)

5. Isolat lokal Steinernema sp. (A4)

6. Kontrol (A0)

Selanjutnya, analisis data dalam penelitian ini menggunakan F-Test dengan uji lanjutan Duncan's Multipple Range Test (DMRT) pada taraf signifikansi 5\% (taraf kepercayaan 95\%).

\section{Tahap-Tahap Pelaksanaan Penelitian} Eksplorasi Agens Hayati

Eksplorasi dilaksanakan bertujuan untuk memperoleh agens hayati bakteri, jamur dan nematoda entomopatogen isolat lokal. Tahapan eksplorasi yaitu:

1. Mencari specimen di lapangan berupa serangga yang diduga terinfeksi jamur, bakteri atau nematoda entomopatogen.

2. Meletakkan umpan larva serangga di dalam kantong kain kassa yang dibenamkan di dalam tanah, karena baik bakteri, jamur maupun nematoda banyak terdapat di dalam tanah lapisan atas.

3. Specimen yang diperoleh dari lapangan yang diduga terinfeksi jamur selanjutnya dimurnikan.

4. Serangga hasil eksplorasi yang sudah terinfeksi kemudian didisinfektan terlebih dahulu, dikeringkan pada kertas hisap steril selanjutnya diisolasikan pada PDA steril pada petridis. kemudian

diinkubasikan pada suhu kamar ( suhu $20^{\circ}-30^{\circ} \mathrm{C}$, RH $90 \%$ ) selama 3-5 hari. 
5. Setelah di media PDA/SDA tumbuh koloni jamur atau bakteri, selanjutnya diambil sedikit dengan menggunakan

6. jarum dan diletakkan pada obyek glass, kemudian diidentifikasi. Jika jamur atau bakteri yang tumbuh masih bercampur dengan jamur atau bakteri lain, dilakukan pemurnian berulang-ulang 3-5 kali sampai diperoleh isolat murni.

7. Eksplorasi nematoda dilakukan dengan metode white trap, yaitu larva serangga umpan yang diduga telah terinfeksi nematoda entomopatogen selanjutnya diletakkan/disusun pada petridish terbalik yang telah dilapisi kertas saring. Petridish yang terdapat larva serangga diletakkan pada petridish yang lebih besar dan berisi air hingga menyentuh kertas saring. Selanjutnya diinkubasikan selama kurang lebih 2 minggu, hingga diperoleh nematoda pada cairan di petridish besar. Melakukan pengamatan di bawah mikroskop untuk mengidentifikasi nematoda entomopatogen yang diperoleh.

\section{Perbanyakan Larva $H$. armigera}

Imago jantan dan betina $H$. armigera ditempatkan dalam kurungan kasa untuk berkopulasi dan menghasilkan telur. Telur yang dihasilkan kemudian ditetaskan didalam tabung reaksi. Ulat yang baru menetas dipelihara dengan pemberian pakan sampai mencapai instar 3. Larva uji yang akan digunakan adalah instar 3 untuk semua perlakuan.

\section{Aplikasi Perlakuan (Uji Screening)}

1. Menyiapkan larva uji berupa larva instar tiga $H$. armigera hasil pembiakan massal yang sebelumnya telah dilaparkan selama 24 jam. Larva uji ditempatkan di dalam cawan petri yang telah dialasi kertas saring, masingmasing 10 ekor larva/ulangan.

2. Menyiapkan masing-masing isolat yang akan diujikan dengan menetapkan konsentrasi sesuai perlakuan. Kerapatan spora $B$. bassiana dihitung dengan haemocytometer dengan menggunakan rumus:

$$
\begin{aligned}
& \text { Kerapatan spora }=\frac{\mathrm{t} \times \mathrm{d}}{10^{6}} \mathrm{X} \\
& \mathrm{n} \times 0,25 \\
& \mathrm{~d}=\text { jumlah kotak yang berisi spora }
\end{aligned}
$$

$\mathrm{n}=$ jumlah kotak yang diamati
Kerapatan populasi invektif juvenil Steinernema dihitung dengan klonning plate sehingga dapat ditentukan konsentrasi 400 $\mathrm{IJ} / \mathrm{ml}$ melalui pengenceran.

3. Aplikasi perlakuan dengan menyemprotkan 1 $\mathrm{ml} /$ ulangan larutan masing-masing isolat

secara merata ke seluruh tubuh larva uji melalui mikropipet.

4. Larva uji diamati dan dipelihara dengan pemberian pakan secara berkala sampai dengan salah satu ulangan mencapai mortalitas $100 \%$.

\section{Parameter Pengamatan}

Parameter-parameter yang diamati pada penelitian tahap I adalah:

1. Gejala kematian serangga uji yaitu mengamati warna kutikula serangga uji setelah mati pada 24, 48, 72 jam setelah perlakuan dan seterusnya hingga diperoleh kematian $100 \%$ pada salah satu ulangan.

2. Persentase mortalitas serangga uji yaitu menghitung jumlah serangga yang mati pada 24, 48, 72 jam setelah perlakuan dan seterusnya hingga diperoleh kematian 100\% pada salah satu ulangan. Mortalitas serangga uji (\%) dikoreksi dengan rumus Abbot, yaitu

Kematian serangga uji $(\%) \frac{=\mathrm{A}-\mathrm{B} \quad \mathrm{X} \quad 100 \%}{100-\mathrm{B}}$

$\mathrm{A}=$ Persentase kematian tiap perlakuan

$\mathrm{B}=$ Persentase kematian kontrol

3. Perilaku serangga uji yaitu mengamati dan mencatat perubahan perilaku larva uji yang berhasil terinfeksi agens hayati.

4. Laju kematian serangga uji yaitu menghitung waktu kematian tercepat dan terlambat yang dibutuhkan oleh larva uji akibat infeksi agens hayati. Penentuan waktu kematian (Lethal Time) dengan menggunakan analisis Probit.

5. Bedah serangga uji yaitu membedah tubuh larva uji untuk memastikan bahwa kematiannya disebabkan oleh infeksi agens hayati.

\section{HASIL DAN PEMBAHASAN}

\section{Persentase Mortalitas Serangga Uji}

Respon serangga uji terhadap perlakuan agens hayati yang umum diamati adalah persentase mortalitas. Mortalitas serangga uji 
Irma W, Dyah N, Cherry T dan Usken F, Patogenistias Bakteri, Jamur Dan NematodaEntomopatogen Terhadap Hama Penggerek Buah Kapas (Gossypium hirsutum L.)

mengindikasikan bahwa agens hayati yang diaplikasikan memiliki kemampuan sebagai patogen terhadap serangga. Hasil analisis ragam yang dilanjutkan dengan uji DMRT terhadap persentase mortalitas Helicoverpa armigera menunjukkan pengaruh yang signifikan dari masing-masing agens hayati (Tabel 1).

Tabel 1. Persentase Mortalitas Helicoverpa armigera

\begin{tabular}{|c|c|c|c|c|c|c|c|c|c|c|c|}
\hline \multirow{4}{*}{$\begin{array}{l}\text { Perla } \\
\text { kuan }\end{array}$} & \multicolumn{11}{|c|}{ Waktu (jam) setelah perlakuan } \\
\hline & & & & & & 1 & & 1 & & 1 & \\
\hline & 2 & 4 & & 9 & & 2 & & 4 & & 6 & \\
\hline & 4 & 8 & & 6 & & 0 & & 4 & & 8 & \\
\hline & 0 . & 0 . & & 0 . & & 0 . & & 0 . & & 0 . & \\
\hline & 0 & 1 & & 3 & & 3 & $\mathrm{a}$ & 3 & & 4 & \\
\hline $\mathrm{Bt}$ & 4 & 6 & $\mathrm{~b}$ & 2 & $\mathrm{~b}$ & 6 & $\mathrm{~b}$ & 8 & $\mathrm{~b}$ & 6 & $\mathrm{~b}$ \\
\hline & 0 . & 0 . & & 0 . & & 0 . & & 0 . & & 0 . & \\
\hline & 0 & 2 & & 4 & & 5 & & 5 & & 6 & \\
\hline Bv 1 & 8 & 6 & $\mathrm{a}$ & 2 & $\mathrm{a}$ & 0 & a & 0 & a & 4 & $\mathrm{a}$ \\
\hline & 0. & 0 . & & 0. & & 0. & & 0 . & & 0. & \\
\hline & 0 & 1 & & 4 & & 4 & & 4 & a & 4 & \\
\hline Bv 2 & 8 & 8 & b & 0 & $\mathrm{a}$ & 0 & $\mathrm{a}$ & 4 & b & 6 & $\mathrm{~b}$ \\
\hline & 0. & 0. & & 0. & & 0. & & 0 . & & 0. & \\
\hline & 0 & 1 & b & 2 & & 3 & & 3 & & 3 & \\
\hline NEP & 8 & 2 & $\mathrm{c}$ & 8 & b & 0 & b & 6 & b & 8 & $\mathrm{~b}$ \\
\hline & 0. & 0. & & 0. & & 0. & & 0. & & 0. & \\
\hline Kont & 0 & 0 & & 0 & & 1 & & 1 & & 2 & \\
\hline rol & 4 & 4 & $\mathrm{c}$ & 8 & $\mathrm{c}$ & 0 & $\mathrm{c}$ & 0 & $\mathrm{c}$ & 2 & $\mathrm{c}$ \\
\hline
\end{tabular}

Angka yang diikuti oleh huruf yang sama pada satu kolom menunjukkan tidak signifikan berdasarkan hasil DMRT pada taraf 5\%

Pengamatan pada 24 jam setelah perlakuan memperlihatkan bahwa persentase mortalitas $H$. armigera masih rendah berkisar $4 \%$ hingga $8 \%$ dan tidak signifikan pada semua agens hayati. Pada 48 jam setelah perlakuan persentase tertinggi terdapat pada perlakuan agens hayati Bv 1 (jamur Beauveria bassiana 1), sedangkan perlakuan lainnya yaitu jamur Beauveria bassiana 2 ( $\mathrm{Bv} 2$ ), bakteri Bacillus thuringiensis (Bt), nematoda Steinernema sp. (NEP) dan kontrol, tidak signifikan. Pengamatan 96 jam setelah perlakuan menunjukkan agens hayati $\mathrm{Bv} 1$ tidak signifikan dengan Bv 2, tetapi signifikan dengan perlakuan lainnya, demikian juga dengan hasil pengamatan pada 120 dan 144 jam setelah perlakuan. Pada pengamatan terakhir 168 jam setelah perlakuan memperlihatkan persentase mortalitas tertinggi adalah agens hayati Bv 1, signifikan dengan agens hayati lainnya, sedangkan di antara agens hayati
Bv 2, Bt dan NEP tidak signifikan, tetapi signifikan dengan kontrol.

Persentase mortalitas $H$. armigera tertinggi yang diakibatkan oleh jamur $B$. bassiana 1 diduga disebabkan oleh kesesuaian inang dibandingkan dengan jamur $B$. bassiana 2, yang nilai persentase mortalitasnya lebih rendah.

Disamping itu dibandingkan dengan bakteri $B$. thuringiensis dan nematoda Steinernema sp., mekanisme kerja dari jamur B. Bassiana diduga lebih efektif karena tidak hanya masuk dan tumbuh menyebar pada setiap bagian tubuh inang, tetapi juga mengeluarkan enzim atau toksin yang mempercepat proses kematian inang. Seperti yang dikemukakan oleh Effendi (2002) dan Untung (1996), bahwa inokulum jamur yang menempel pada tubuh serangga inang akan berkecambah dan berkembang membentuk tabung kecambah, kemudian masuk menembus kulit tubuh. Penembusan dilakukan secara mekanis dan atau kimiawi dengan mengeluarkan enzim atau toksin. Pada proses selanjutnya, jamur akan bereproduksi di dalam tubuh inang. Jamur akan berkembang dalam tubuh inang dan menyerang seluruh jaringan tubuh, sehingga serangga mati. Miselia jamur menembus ke luar tubuh inang, tumbuh menutupi tubuh inang dan memproduksi konidia. Dalam hitungan hari, serangga akan mati. Serangga yang terserang jamur Beauveria bassiana akan mati dengan tubuh mengeras seperti mumi dan jamur menutupi tubuh inang dengan warna putih. Proses perkembangan cendawan dalam tubuh inang sampai inang mati berjalan sekitar 7 (tujuh) hari.

Berbeda dengan jamur B. bassiana yang bisa tumbuh menyebar pada setiap bagian tubuh inang, maka mekanisme serangan bakteri $B$. thuringiensis pada umumnya pertama kali terjadi pada organ saluran makanan. Tanda-tanda awal serangan bakteri pada serangga berhubungan dengan aktivitas makan dan pengolahan bahan makanan. Pada tahap awal aktivitas makan serangga menurun, bahkan dapat terhenti. Gejala muntah (keluarnya cairan dari mulut serangga) dan diare (faeces atau kotoran serangga tidak normal seperti padatan) dapat diamati. Pada saluran makanan dapat terjadi paralysis. Serangga juga menunjukkan penurunan aktivitas gerakan, serangga menjadi lemah dan kurang tanggap terhadap sentuhan. Pada infeksi lebih lanjut, paralysis dapat terjadi pada seluruh tubuh dan diikuti oleh septisemi dan berakhir dengan kematian serangga, dengan kondisi tubuh serangga lunak dan berisi lendir yang merupakan massa 
bakteri. Kematian larva sudah mulai terjadi satu hari setelah aplikasi $B$. thuringiensis dan persentase kematian meningkat sampai lima hari setelah aplikasi (Trizelia, 2001).

$$
\text { Sedangkan mekanisme serangan }
$$

nematode Steinernema sp. dimulai dengan masuknya nematoda ke dalam tubuh serangga hama melalui lubang alami, seperti mulut, anus, trachea, stigma dan atau menembus langsung kutikula (Bedding and Molyneux, 1992; Sulistyanto and Ehlers, 1997). Indikasi ini memperihatkan bahwa proses penetrasi nematoda entomopatogen didukung oleh aktifitas dari enzym protease yang diproduksinya (Roque et al., 1994). Setelah masuk kedalam tubuh inang, nematoda entomopatogen melepaskan bakteri ke dalam haemolymphe, setelah 50 hingga 120 jam serangga inang mati (Subagiya, 2005). Gejala serangan nematoda entomopatogen terlihat pada tubuh serangga yang berubah warna menjadi coklat karamel karena berisi nematoda entomopatogen dan bakteri simbion.

Selain itu faktor-faktor yang dapat mempengaruhi toksisitas agens hayati terhadap serangga uji antara lain adalah proses fisiologi dan biokimia, meliputi penetrasi agens hayati melalui integumen atau dinding saluran pencernaan, translokasi ke bagian organ tubuh sasaran, pengikatan dan penyimpanan pada jaringan tubuh tertentu, metabolisme oleh berbagai enzim pengurai dalam tubuh dan pembuangan keluar tubuh, serta penetrasi melalui lapisan pelindung bagian sasaran dan interaksi agens hayati dengan bagian sasaran (Prijono, 1988).

\section{Waktu Kematian (Lethal Time) Serangga Uji oleh Agens Hayati}

Waktu kematian serangga uji pada umumnya dinyatakan dengan nilai $\mathrm{LT}_{50}$ (Lethal Time 50), yaitu waktu yang diperlukan oleh agens hayati untuk mengakibatkan mortalitas serangga uji sebesar $50 \%$. Nilai LT $_{50}$ mengindikasikan kecepatan kerja agens hayati (Prijono, 1988). Waktu kematian yang dibutuhkan oleh masingmasing agens hayati dalam menekan larva $H$. armigera dan Earias sp.dapat dilihat pada Tabel 2.

Tabel 2. Waktu Kematian (Lethal Time) oleh Agens Hayati terhadap Helicoverpa armigera.

\begin{tabular}{lc}
\hline Perlakuan & $\begin{array}{c}\text { Waktu Kematian } \\
(\text { Lethal } \\
\text { Time }) \text { LT }_{50}(\text { jam })\end{array}$ \\
\hline $\mathrm{Bt}$ & 189 \\
$\mathrm{Bv} 1$ & 128 \\
$\mathrm{Bv} 2$ & 175 \\
$\mathrm{NEP}$ & 245 \\
\hline
\end{tabular}

Pada Tabel 2 terlihat bahwa agens hayati isolat lokal Bv 1 memiliki waktu kematian yang lebih pendek dibandingkan agens hayati lainnya, yaitu 128 jam, diikuti dengan $\mathrm{Bv} 2$, yaitu 175 jam, selanjutnya Bt yaitu 189 jamdan terakhir NEP yaitu 245 jam. Hal ini menunjukkan kecepatan kerja dari masing-masing agens hayati. Jamur $B$. bassiana menunjukkan hasil tercepat diduga karena mekanisme kerjanya yang relatif cepat, sebagaimana yang dikemukakan oleh Steett dan Wood (2008), bahwa mekanisme kerja jamur $B$. bassiana meliputi : (1) perlekatan pada stadium infeksi untuk kutikula serangga; (2) germinasi dari konidium dan penetrasi kutikula serangga melalui sebuah germ tube dari konidium; (3) pertumbuhan dari cendawan di dalam badan serangga (hemosel) dan penyebab kematian kematian serangga; (4) penetrasi dari cendawan untuk permukaan serangga dan pembentukan dari konidia (dengan kelembaban dan suhu yang cocok).

Selain itu kesesuaian inang dengan agens hayati juga berpengaruh terhadap cara kerja dari agens hayati, seperti pendapat dari Fuxa dan Tanada, 1987; McNaughton dan Wolf, 1998.dalam Subagiya (2008), bahwa organisme yang hidup pada inang yang sesuai akan tumbuh dan berkembang dengan baik karena kebutuhan nutrisi dapat dipenuhi dari inang, sehingga kematian serangga inang dapat berlangsung dengan cepat. Heimpel dan Angus, 1959 dalam Trizelia (2001) mengelompokkan serangga ke dalam tiga tipe berdasarkan kerentanannya terhadap $B$. thuringiensis. Tipe I adalah spesies yang mati karena toksin dan serangga mengalami general paralysis dan ada kenaikan $\mathrm{pH}$ darah sebesar 1.01,5 unit, contohnya adalah Bombyx mori, Manduca Sexta dan larva nyamuk. Tipe II, serangga tidak mengalami general paralysis dan serangga mati tanpa adanya perubahan $\mathrm{pH}$ darah. Sebagian besar larva Lepidoptera masuk ke dalam kelompok ini. Tipe III, serangga tidak mengalami general paralysis dan serangga mati tidak hanya disebabkan oleh kristal saja tetapi juga membutuhkan adanya spora, contohnya Anagasta kuehniella dan Galleria mellonella. Toksisitas $B$. thuringiensis terhadap serangga dipengaruhi oleh strain bakteri dan spesies serangga yang terinfeksi. Faktor pada bakteri yang mempengaruhi toksisitasnya adalah struktur kristalnya, yang pada salah satu strain mungkin mempunyai ikatan yang lebih mudah dipecah oleh enzim yang dihasilkan serangga dan ukuran molekul protein yang menyusun kristal, serta susunan molekul asam amino dan kandungan karbohidrat dalam kristal.

Sedangkan nematoda entomopatogen Steinernema sp.memerlukan waktu paling lama 
Irma W, Dyah N, Cherry T dan Usken F, Patogenistias Bakteri, Jamur Dan NematodaEntomopatogen Terhadap Hama Penggerek Buah Kapas (Gossypium hirsutum L.)

diduga selain karena kesesuaian inang, juga tergantung dari simbiosis dengan bakteri simbionnya. Dalam menginfeksi hama, nematoda entomopatogen bersimbiose secara mutualistis dengan bakteri Xenorhabdus sp. yang hidup di dalam saluran pencernaannya. Sel-sel bakteri yang keluar dari saluran pencernaan nematoda akan menginfeksi hemolimfa serangga, kemudian berkembang dan membunuhya dengan menyebabkan keracunan darah (septicemia) (Aguillera et al., 1993; Mráck et al., 1994 dalam Indrayani, 2008).

Hasil analisis Probit $\mathrm{LT}_{50}$ dari masingmasing agens hayati terhadap larva $H$. armigeramenghasilkan persamaan garis regresi seperti terlihat pada Tabel 3.

Tabel 3. Persamaan Garis Regresi Hasil Pendugaan Hubungan Log Waktu Kematian dengan Probit Kematian

\begin{tabular}{lc}
\hline $\begin{array}{l}\text { Perla } \\
\text { kuan }\end{array}$ & $\begin{array}{c}\text { Persamaan Garis } \\
\text { Regresi }\end{array}$ \\
\hline Bt & $\mathrm{y}=0,1237+2,1421 \mathrm{x}$ \\
Bv 1 & $\mathrm{y}=0,7702+2.0079 \mathrm{x}$ \\
Bv 2 & $\mathrm{y}=1,0462+1,7619 \mathrm{x}$ \\
NEP & $\mathrm{y}=0,8226+1,7478 \mathrm{x}$ \\
\hline
\end{tabular}

Berdasarkan persamaan garis regresi di atas diperoleh grafik pendugaan hubungan log waktu kematian dengan probit kematian, seperti terlihat pada Gambar 1.

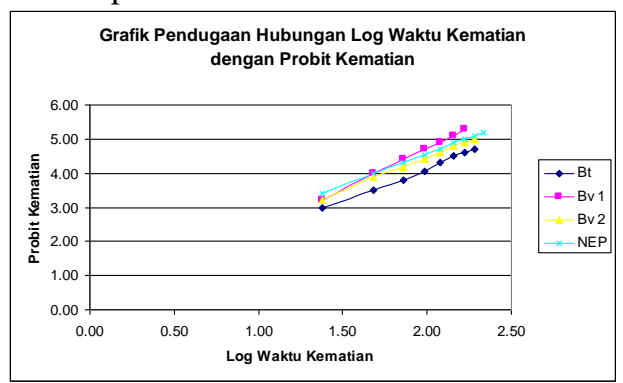

Gambar 1. Grafik Pendugaan Hubungan Log Waktu Kematian dengan Probit Kematian dari Agens Hayati terhadap Helicoverpa armigera

Gambar 1 memperlihatkan agens hayati isolat lokal $B$. bassiana 1 ( $\mathrm{Bv} 1$ ) memiliki waktu kematian tercepat, diikuti oleh $B$. bassiana 2, B. thuringiensis dan nematoda Steinernema sp. Persamaan garis regresi yang dihasilkan dari analisis probit waktu kematian $\left(\mathrm{LT}_{50}\right)$ menggambarkan hubungan antara waktu yang diperlukan oleh perlakuan berbagai agens hayati untuk menyebabkan kematian larva uji sebesar
50\%. Angka kematian sebesar 50\% menunjukkan bahwa agens hayati mampu menekan larva uji, semakin cepat waktu yang diperlukan maka agens hayati, maka agens hayati semakin efektif dalam menekan larva uji (Prijono, 1988). Dalam hal ini agens hayati $B$. Bassiana 1 paling efektif dalam menekan larva uji dibandingkan agens hayati $B$. thuringiensis, B. bassiana 2 dan Steinernema $\mathrm{sp.}$

\section{KESIMPULAN DAN SARAN}

\section{Kesimpulan}

Berdasarkan hasil dan pembahasan dapat diambil beberapa kesimpulan sebagai berikut:

1. Agens hayati isolat lokal bakteri Bacillus thuringiensis (Bt), jamur Beauveria bassiana (Bv) dan nematoda entomopatogen Steinernema carpocapsae (NEP) berpotensi dalam menekan hama penggerek buah kapas Helicoverpa armigera.

2. Agens hayati isolat lokal jamur Beauveria bassiana 1 (Bv 1) paling efektif dalam menekan hama hama penggerek buah kapas Helicoverpa armigera.

3. Waktu kematian $\left(\mathrm{LT}_{50}\right)$ tercepat dicapai oleh agens hayati isolat lokal jamur Beauveria bassiana 1 ( $\mathrm{Bv} 1)$, yaitu 128 jam.

Saran

Berdasarkan penelitian yang telah dilaksanakan, maka disarankan untuk:

1. Perlu adanya penelitian lebih lanjut untuk menguji efektivitas agens hayati bakteri, jamur dan nematoda isolat lokal terhadap hama utama kapas di lapang.

2. Perlu adanya penelitian lebih lanjut mengenai efektivitas agens hayati isolat lokal terhadap hama lainnya

\section{DAFTAR PUSTAKA}

Bank Ekspor Indonesia. 2007. Saatnya Merajut Industri Kapas. Jakarta.

BPTP Sulsel. 2002. Pengendalian Hama Terpadu (PHT) Kapas. Disbun Sulawesi Selatan.

Chalid, N.I. 2004. Pedoman Penerapan PHT pada Agribisnis Tanaman Cabai. Direktorat Jendral Bina Produksi Hortikultura Direktorat Perlindungan Hortikultura. Jakarta. 
Direktorat Proteksi Tanaman Perkebunan. 2000. Musuh Alami dan Hama pada Kapas. Proyek Pengendalian Hama Terpadu Perkebunan Rakyat Departemen Kehutanan dan Perkebunan. Jakarta.

Ditjenbun Deptan. 2008. Harapan Masa Depan Petani Kapas Hybrida Indonesia. Deptan. Jakarta.

Ehlers, R.U. 2001. Mass Production of Entomopathogenic Nematodes for Plant Protection. Applied Microbiology Biotechnology 56 : 623-633.

Erawati, D.N. 2006. Patogenisitas Nematoda dan Jamur Entomopatogen Terhadap Hama Tanaman Tomat (Spodoptera litura F.). Inovasi. 6 (3) : $228-235$.

2007 a. Potensi Nematoda dan Jamur Entomopatogen Terhadap Hama Utama Untuk Meningkatkan Produktivitas Tomat (Lycopersicum esculentum). Inovasi. 7 (1) : $8-13$.

2007 b. Efektivitas Agens Hayati Sebagai Pengendali Hama Utama Untuk Meningkatkan Produktivitas Tanaman Tomat. (belum dipublikasikan)

Gomes, K.A. dan A.A. Gomes. 1995. Prosedur Statistik untuk Penelitian Pertanian (terjemahan oleh E. Sjamsudin dan J.S. Baharsjah). UI-Press. Jakarta.

Herman, M. 2003. Status Perkembangan Kapas Bt. Balai Penelitian Bioteknologi dan Sumberdaya Genetik Pertanian, Bogor.

Hoffmann, M.P. and A.C. Frodsham. 1993. Natural Enemies of Vegetable Insect Pests. . Cooperative Extension, Cornell University, Ithaca, NY. 63 pp.

Indrayani, I.G.A.A. 2008. Peranan Morfologi Tanaman untuk Mengendalian Pengisap Daun Amrasca biguttula (Ishida). Perspektif Vol. 7 No. 1 / Juni 2008. Hlm 47 - 54. Balai Penelitian Tanaman Tembakau dan Serat. Malang.

Knowles, B.H. 1994. Mechanism of action of Bacillus thuringiensis insecticidal deltaendotoxins. In Advances in Insect
Physiology, Volume 24 (ed. PD Evans) pp.275308. Academic Press, London.

Navon, A., V.K. Nagalakshmi, S. Levski, L. Salame dan I. Glazer. 2002. Effectiveness of Entomopathogenic Nematodes in an Aglinat Gel Formulation against Lepidopterous Pests. Biologycal Science and Technology. 12 : 737-746.

Pracaya. 2007. Hama dan Penyakit Tanaman (edisi revisi). Penebar Swadaya. Jakarta.

Prijono, D. 1988. Pengujian Indektisida. Jurusan Hama dan Penyakit Tumbuhan Fakultas Pertanian Instiut Pertanioan Bogor

Raharjo, K. 1998. Penggunaan Jamur Metarhizium anisopliae dan Beauveria bassiana untuk Mengendalikan Beberapa Jenis Hama. Kumpulan Makalah Gelar Teknologi Spesifik Lokasi. Karawang, 5-9 Oktober 1998. hal 36-40.

Robert, D.W. 1981. Toxins of Entomopathogenic Fungi dalam H.D Burges (Ed.) Microbial Control Pest and Plant Diseases.Academic Press Inc. New York. 949 p.

Soeroso, B., Y.H. Agus dan K. Astuti. 1993. Pengaruh Insektisida Klorpirifos, Jamursida Benomyl dan Jamur Beauveria bassiana Terhadap Tingkat Kerusakan, Pertumbuhan dan Hasil Tanaman Kedelai Varietas Wilis. Makalah Simposium Patologi Serangga. PEI Cabang Yogyakarta. Yogyakarta. 8 p.

Sriganti, E. 2000. Toksisitas Bacillus thuringiensis subsp Berliner dan subsp aizawai terhadap larva Crocidolomia binotalis Zell. (Lepidoptera; Pyralidae) dan Spodoptera litura Fab. (Lepidoptera; Noctuidae). Jurusan Hama dan Penyakit Tumbuhan Fakultas Pertanian IPB. Bogor. $28 \mathrm{p}$.

Steett, D.A. and S.A. Wood. 2008. Beauveria bassiana for Mormon Crickets. Hand Book. Section VII: Future Directions. Grasshoppers: Their Biology, Identification and Management. 1 - 7. http://www.Sidney.ars.usda.gov/grass hopper/handbook/VII/Vii_6.htm. Januari-2008).

Sulistyanto, D. 1999. Nematoda Entomopatogen Steinernema spp. dan Heterorhabditis spp. 
Irma W, Dyah N, Cherry T dan Usken F, Patogenistias Bakteri, Jamur Dan NematodaEntomopatogen Terhadap Hama Penggerek Buah Kapas (Gossypium hirsutum L.)

Isolat Lokal Sebagai Pengendali Hayati Serangga Hama Perkebunan. Makalah Lustrum Universitas Jember, 2 Desember $1999: 1-12$.

Subandrijo. 2000. Penerapan Teknologi Pengendalian Hama Terpadu pada Tanaman Kapas. Badan Penelitian dan Pengembangan Kahutanan. Jakarta.

Subandrijo, Sudarmo, Subiyakto. 2001. UsahaUsaha Mengurangi Pemakaian Insektisida dalam Pengendalian Kapas. Prosiding Simposium Hasil Penelitian dan Pengembangan Tanaman Industri (Ke-1, 25-27 Juli 1990, Bogor), 1990 : p. $759-$ 771.

Trizelia. 2001. Pemanfaatan Bacillus thuringiensis untuk Pengendalian Hama Crocidolomia binotalis. Makalah Falsafah Sains. Program Pascasarjana/S3. Institut Pertanian Bogor. Bogor.

Untung, K. 1996. Pengendalian Hayati dalam Kerangka Konversi Keanekaragaman Hayati. Makalah Seminar Nasional Pengendalian Hayati. Universitas Gadjah Mada. Yogyakarta. 25 November 1996. 13 p.

Widayat, W. dan D.J. Rayati. 1993. Hasil Penelitian Jamur Entomopatogenik Lokal dan Prospek Penggunaannya Sebagai Insektisida Hayati. Makalah Simposium Patologi Serangga. PEI Cabang Yogyakarta.Yogyakarta. $13 \mathrm{p}$. 